\title{
Vegetation, plant biomass, and net primary productivity patterns in the Canadian Arctic
}

\author{
W. A. Gould, ${ }^{1}$ M. Raynolds, ${ }^{2}$ and D. A. Walker ${ }^{2}$ \\ Received 13 June 2001; revised 16 January 2002; accepted 23 January 2002; published 30 January 2003.
}

[1] We have developed maps of dominant vegetation types, plant functional types, percent vegetation cover, aboveground plant biomass, and above and belowground annual net primary productivity for Canada north of the northern limit of trees. The area mapped covers 2.5 million $\mathrm{km}^{2}$ including glaciers. Ice-free land covers 2.3 million $\mathrm{km}^{2}$ and represents $42 \%$ of all ice-free land in the Circumpolar Arctic. The maps combine information on climate, soils, geology, hydrology, remotely sensed vegetation classifications, previous vegetation studies, and regional expertise to define polygons drawn using photo-interpretation of a 1:4,000,000 scale advanced very high resolution radiometer (AVHRR) color infrared image basemap. Polygons are linked to vegetation description, associated properties, and descriptive literature through a series of lookup tables in a graphic information systems (GIS) database developed as a component of the Circumpolar Arctic Vegetation Map (CAVM) project. Polygons are classified into 20 landcover types including 17 vegetation types. Half of the region is sparsely vegetated $(<50 \%$ vegetation cover), primarily in the High Arctic (bioclimatic subzones A-C). Whereas most $(86 \%)$ of the estimated aboveground plant biomass $\left(1.5 \times 10^{15} \mathrm{~g}\right)$ and $87 \%$ of the estimated above and belowground annual net primary productivity $\left(2.28 \times 10^{14} \mathrm{~g}\right.$ $\mathrm{yr}^{-1}$ ) are concentrated in the Low Arctic (subzones D and E). The maps present more explicit spatial patterns of vegetation and ecosystem attributes than have been previously available, the GIS database is useful in summarizing ecosystem properties and can be easily updated and integrated into circumpolar mapping efforts, and the derived estimates fall within the range of current published estimates. INDEX TERMS: 1640 Global Change: Remote sensing; 1615 Global Change: Biogeochemical processes (4805); KEYWORDS: arctic vegetation, bioclimatic zones, Canada, plant biomass, productivity, vegetation mapping

Citation: Gould, W. A., M. Raynolds, and D. A. Walker, Vegetation, plant biomass, and net primary productivity patterns in the Canadian Arctic, J. Geophys. Res., 108(D2), 8167, doi:10.1029/2001JD000948, 2003.

\section{Introduction}

[2] The Canadian Arctic makes up over one third of the Circumpolar Arctic region and is the least well-known region in terms of vegetation patterns and ecosystem properties. There is a long history of botanical and ecological study in Canada [Fernald, 1911; Raup, 1930; Abbe, 1936; Porsild, 1937; Beschel, 1961; Bliss and Wein, 1972; Bliss, 1977; Bliss and Svoboda, 1984; Edlund and Alt, 1989; Svoboda and Freedman, 1988; Gould and Walker, 1997; Lévesque, 1997; Henry, 1998; Lévesque and Svoboda, 1999], vegetation mapping [Edlund, 1976, 1980, 1983, 1990b], and remote sensing [Epp and Matthews, 1991; Cihlar and Beaubien, 1998; Gould, 2000] but until recently there has not been an attempt to link satellite imagery, GIS and vegetation mapping techniques with current understanding of vegetation patterns and properties over the whole Canadian Arctic. An important reason to undertake

\footnotetext{
${ }^{1}$ International Institute for Tropical Forestry, Rio Piedras, Puerto Rico.
}

${ }^{2} \mathrm{IAB}$, University of Alaska, Fairbanks, Alaska, USA. such analyses is to get a better picture of the current spatial pattern of vegetation and associated ecosystem properties (e.g., canopy cover and height, carbon sequestration, carbon storage, wildlife habitat quality, and spectral characteristics) at the continental and circumpolar scale.

[3] Climate is the primary control on vegetation composition in the Arctic [Walker, 2000]. Climate models and observations indicate significant climate changes can be expected, with a complex pattern of warming in some Arctic areas and cooling in others, which will affect vegetation patterns [Oechel et al., 1997]. Changing vegetation patterns will in turn have feedbacks to climate through vegetation controlled changes in albedo, surface roughness, evapotranspiration rates, energy flux, and snow redeposition [Eugster et al., 2000; Beringer et al., 2001; Sturm et al., 2001]. Impact of vegetation change on wildlife and human activity will likely have global importance [Conservation of Arctic Flora and Fauna (CAFF), 1996; Callaghan et al., 2001]. The Canadian Arctic has several of the Arctic's most extensive caribou migration routes and calving grounds, important bird breeding areas, a uniquely Arctic flora in the northern regions. Inuit cultural heritage, governmental structure and current land-use policy in 
Nunavut (most of the Canadian Arctic) is strongly linked to wildlife and vegetation patterns. An understanding of current vegetation can serve 1) as input to modeling efforts predicting future vegetation patterns and ecosystem properties related to climate change; 2) aid in the conservation of Arctic flora and fauna [CAFF, 1996; Callaghan et al., 2001]; and 3) aid in Inuit and nonnative land-use and management decisions.

[4] Vegetation serves as a both an integrator and indicator of climate and ecosystem properties [Braun-Blanquet, 1965; Walker, 1995]. Vegetation patterns in the Arctic are primarily controlled by climate, geology, topography, and glacial history [Edlund, 1990b; Yurtsev, 1994; Bliss and Matveyeva, 1992; Chernov and Matveyeva, 1997; Walker, 2000]. Individual plant species respond independently to gradients in climate, soil chemistry, and moisture but suites of species often respond similarly to these gradients and give us recognizable patterns of plant community composition across landscapes [Braun-Blanquet, 1965]. These communities, due to similarities in composition in response to abiotic controls, are often relatively consistent from place to place in terms of ecosystem properties such as biodiversity [Chapin and Körner, 1995; Chernov and Matveyeva, 1997; Callaghan et al., 2001], productivity [Webber, 1978; Bliss and Matveyeva, 1992], plant biomass, root:shoot ratios, leaf area index [Bliss and Matveyeva, 1992], Normalized Difference of Vegetation Index (NDVI) response [Stow et al., 1989; Shippert et al., 1995; Walker et al., 2001, 2002], animal activity [Chernov and Matveyeva, 1997], soil properties, energy and material fluxes [Reeburgh et al., 1998; Walker et al., 1998], growth form dominance, and amount of vegetation cover. Specific plant communities in any landscape can vary from rare to common in occurrence and extent. Ecosystem properties associated with common plant communities can be measured at the plot level and extrapolated over large areas.

[5] Climatic control on vegetation is expressed in the Canadian and Circumpolar Arctic as a distinct pattern of bioclimatic zonation from north to south recognized by shifts in growth form dominance, amount of vegetation cover, species diversity, plant community composition, and associated ecological properties [Edlund and Alt, 1989; Edlund, 1990a; Chernov and Matveyeva, 1997; Elvebakk et al., 1999; Walker, 2000; Gould et al., 2002a]. Bioclimatic zones can be readily distinguished in some areas of the Arctic using advanced very high resolution radiometer (AVHRR) satellite imagery. This is possible where shifts in vegetation with corresponding spectral differences are abrupt due to the coincidence of climatic and substrate boundaries, or to steep gradients in summer temperatures. This occurs on Alaska's North Slope and on the Taimyr Peninsula in Russia [Chernov and Matveyeva, 1997; Walker, 2000]. Bioclimatic zonation patterns are less readily apparent in the Canadian Arctic, where the climatic gradient (i.e., mean July temperature gradient of $12^{\circ} \mathrm{C}$ to $<3^{\circ} \mathrm{C}$ ) stretches across 1000 s of kilometers of heterogeneous landscapes, including the Arctic Archipelago complex of islands, open and frozen ocean, mountains, coarse calcareous plateaus and areas of Baffin Island, the Labrador and Ungava Peninsulas, and Keewatin dominated by exposed granitic bedrock. Nevertheless, zonation patterns can be delimited based on climatic patterns and vegetation distributions
[Edlund and Alt, 1989; Edlund, 1990b; Yurtsev, 1994; Elvebakk et al., 1999; Walker, 2000; Gould et al., 2002a, $2002 \mathrm{~b}$ ]. These bioclimatic zones are useful in interpreting satellite imagery and ancillary data in order to map vegetation at sites where no field studies have been initiated [Walker, 1999].

[6] Maps and summary data presented here are a component of the Circumpolar Arctic Vegetation Map (CAVM) project [Walker and Lillie, 1997; Raynolds and Markon, 2001]. This international effort aims to map vegetation and associated characteristics of the circumpolar region. Using uniform methods among all the circumpolar countries, mapped landscape units are linked to vegetation description, associated properties, and descriptive literature through a GIS database. Our primary objectives were to 1) compile data to develop the GIS database for Canada; 2) derive maps of vegetation, dominant plant functional type, percent vegetation cover, plant biomass, and annual net primary productivity (ANPP); and 3) produce spatial and summary estimates will be useful for global estimates of plant biomass and productivity, analyses of vegetation change, and wildlife distribution patterns.

\section{Methods}

\subsection{Vegetation Map}

[7] Mapping procedures followed the CAVM methods which combine information on soils, bedrock and surficial geology, hydrology, remotely sensed vegetation classifications, NDVI, previous vegetation studies, and regional expertise of the mapping scientists [Walker and Lillie, 1997; Walker, 1999; Raynolds and Markon, 2001; Gould et al., 2002a, 2002b]. The information is used to define polygons representing homogeneous landscape units dominated by one type of topographic feature (e.g., hills, plains, plateaus, mountains, valleys) and moisture regime (e.g., dry, mesic, wet). Polygon boundaries are drawn using photo-interpretation of a 1:4,000,000 scale AVHRR false color infrared image basemap. The circumpolar basemap was created using NOAA-AVHRR $1 \mathrm{~km}^{2}$ data from the summers of 1993 and 1995, relatively warm years with minimum cloud and snow cover. While vegetation response to changing climate will ultimately alter AVHRR derived information such as NDVI, our primary use of the AVHRR and NDVI signals was in interpreting landscape and vegetation boundaries. The cloud-free and snow-freecomposite image was a key element in promoting consistency in map products among the circumpolar (CAVM) mapping groups.

[8] Determining vegetation within mapped polygons was a process of 1) identifying landscape units (which combine information on soils, bedrock and surficial geology, hydrology, and elevation), 2) compiling information from previous vegetation studies, 3) analyzing satellite measures of NDVI in order to compare relative levels of greenness across the landscape [Walker, 2000], 4) determining the location of units with climatic subzones, and 5) using expert knowledge to infer probable vegetation types from these data sources in order to create a GIS database and lookup tables linking polygons to dominant and subdominant vegetation. Useful information from previous studies (for any given area) included information on the 


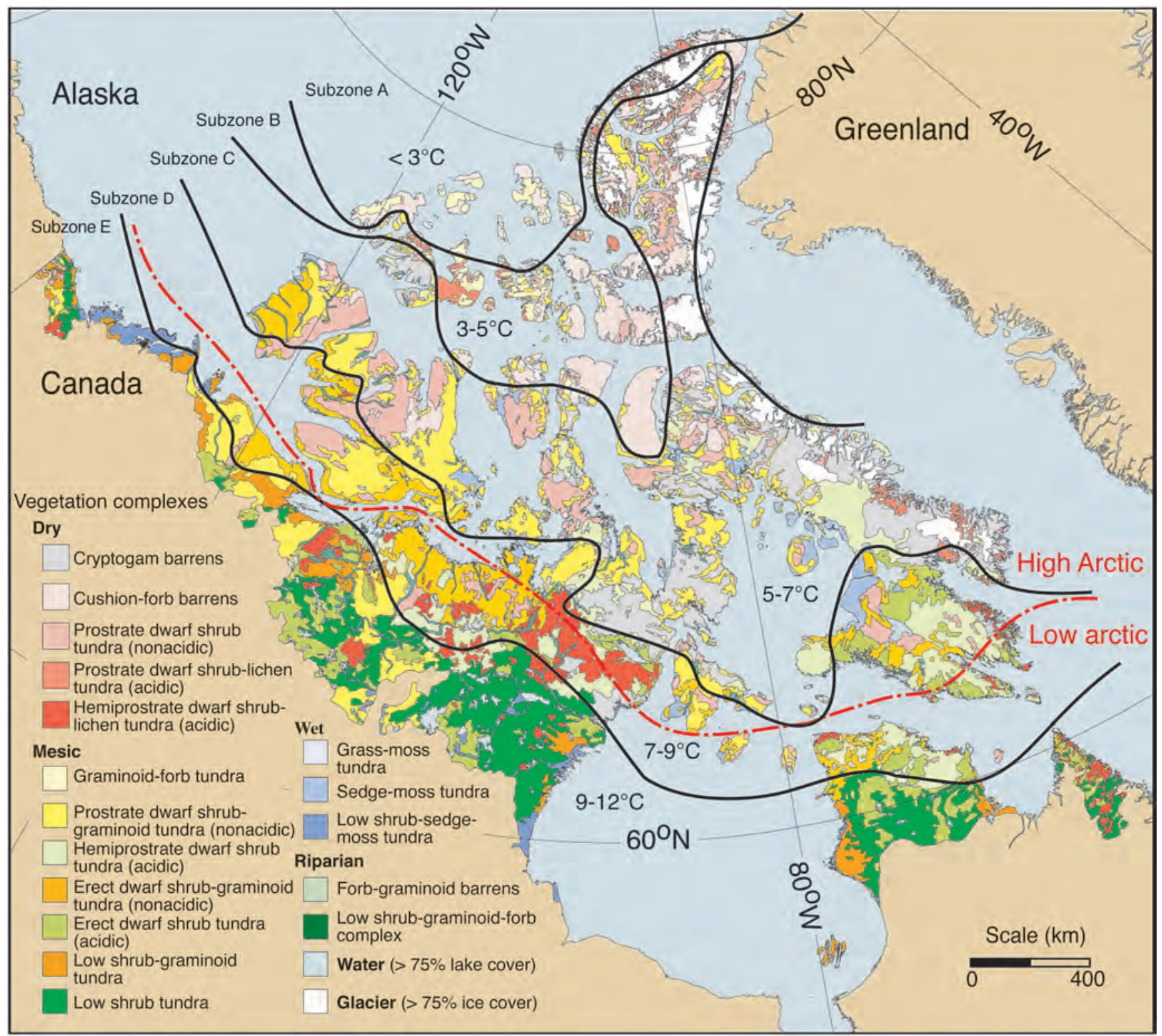

Figure 1. Vegetation map of the Canadian Arctic north of treeline (modified from Gould et al. [2002b]). Derived from AVHRR interpretation and ancillary information on soils, bedrock and surficial geology, hydrology, climate, and previous vegetation studies. Five bioclimatic subzones of the Arctic tundra zone are indicated including subzone A: dominated by barrens and cushion forb growth forms, subzone B: dominated by barrens, cushion forbs and prostrate dwarf shrubs, subzone C: dominated by prostrate and hemiprostrate dwarf shrubs, subzone D: dominated by erect dwarf shrubs and graminoids, and subzone E: dominated by low shrubs and graminoids. Subzonal boundaries are modified from Edlund [1990b], Yurtsev [1994], Elvebakk et al., [1999], and Gould et al. [2002a]. The High Arctic-Low Arctic division follows Bliss and Matveyeva [1992]. Mean July temperatures are given for each subzone.

presence of plant species or vegetation types, plant community composition, the extensiveness of particular vegetation types, biomass and productivity measures, and linkages of vegetation type with landscape characteristics. A set of 2864 polygons were classified into 32 unique landscape units in the GIS database for the Canadian Arctic. Some of these units shared similar dominant vegetation (covering more than $50 \%$ of surface any polygon) but differed in subdominant vegetation. They are here simplified to a set of 20 landcover classes with distinct dominant vegetation types (Figure 1).

\subsection{Derived Maps}

[9] Vegetation characteristics including dominant plant functional type, percent vegetation cover, aboveground plant biomass, and annual net primary productivity were mapped by linking measures and estimates of these biophysical attributes (obtained from the literature, Table 1) 
Table 1. Relevant references of primary ${ }^{*}(p)$ and review $(r)$ papers with locations and information used for mapping vegetation attributes. Vegetation information includes plant community composition descriptions (composition), biomass and productivity measures and estimates, plant species distribution or location information (distribution), percent cover of vegetation (cover), and vegetation maps

\begin{tabular}{|c|c|c|c|}
\hline & Location & & Information obtained \\
\hline Lambert [1968] & Richardson and British Mountains & $p$ & Composition \\
\hline Bliss et al. [1973] & Circumpolar & $r$ & Biomass and productivity estimates by vegetation type \\
\hline Edlund $[1976]$ & North-Central Keewatin & $p$ & Map, distribution, cover \\
\hline Bliss $[1977]$ & Truelove Lowland, Devon Island & $p$ & Composition, distribution, biomass, productivity, cover \\
\hline Svoboda $[1977]$ & Truelove Lowland, Devon Island & $p$ & Productivity \\
\hline Zoltai and Johnson [1979] & District of Keewatin & $p$ & Composition, distribution, cover \\
\hline Edlund $[1980]$ & Lougheed Island & $p$ & Map, distribution, cover \\
\hline Komárková and Webber [1980] & Atkasook, Alaska, North Slope & $p$ & Map, biomass \\
\hline Thompson $[1980]$ & Boothia Peninsula, Northern Keewatin & $p$ & Composition, distribution, cover \\
\hline Rieznicek and Svoboda [1982] & Coral Harbour, Southampton Island & $p$ & Composition, biomass, productivity, cover \\
\hline Sheard and Geale [1983] & Polar Bear Pass, Bathurst Island & $p$ & Composition \\
\hline Bliss and Svoboda [1984] & Melville, Ellef Ringnes, King Christian Islands & $p$ & Composition, biomass, productivity \\
\hline Bliss et al. $[1984]$ & Canadian High Arctic & $r$ & Composition, biomass, productivity \\
\hline Bliss $[1986]$ & Circumpolar & $r$ & Composition, biomass, productivity \\
\hline Thannheiser [1987] & Banks, Victoria Islands & $p$ & Composition, distribution \\
\hline Bliss [1988] & North America & $r$ & Composition, species distribution, biomass, productivity, cover \\
\hline Svoboda and Freedman [1988] & Alexandra Fiord, Ellesmere Island & $p$ & Composition, biomass \\
\hline Thannheiser [1988] & Cambridge Bay, Victoria Island & $p$ & Composition \\
\hline Bergeron and Svoboda [1989] & Sverdrup Pass, Ellesmere Island & $p$ & Composition \\
\hline Edlund and Alt [1989] & Queen Elizabeth Islands & $r$ & Distribution \\
\hline Muc et al. [1989] & Alexandra Fiord, Ellesmere Island & $p$ & Composition \\
\hline Edlund [1990a] & Queen Elizabeth Islands & $p$ & Map, distribution, cover \\
\hline Edlund [1990b] & Canadian Arctic Archipelago & $p$ & Distribution \\
\hline Shaver and Chapin [1991] & Alaska North Slope & $p$ & Biomass and productivity measures by vegetation type \\
\hline Bliss and Matveyeva [1992] & Circumpolar & $r$ & Composition, distribution, biomass, productivity, cover \\
\hline Schaefer and Messier [1994] & Southeastern Victoria Island & $p$ & Composition \\
\hline Walker et al. [1994] & Alaska North Slope & $p$ & Composition \\
\hline Bliss [1995] & Circumpolar & $r$ & Composition, distribution, biomass, productivity, cover \\
\hline Gilmanov [1995] & North American Arctic & $r$ & Biomass, productivity \\
\hline Levesque [1997] & Ellesmere Island & $p$ & Composition, biomass, distribution, cover \\
\hline Shaver et al. [1997] & Alaska North Slope & $p$ & Biomass and productivity measures by vegetation type \\
\hline Gould and Walker [1999] & Bathurst Inlet & $p$ & Composition, distribution, cover \\
\hline Gould $[2000]$ & Bathurst Inlet & $p$ & Map, cover \\
\hline Walker [1999] & Alaska North Slope & $r$ & Maps, biomass, productivity, cover \\
\hline Walker $[2000]$ & North America & $r$ & Composition, biomass, productivity, cover \\
\hline Walker et al. [2001] & Circumpolar & $r$ & Biomass \\
\hline
\end{tabular}

${ }^{*}$ Primary papers are those with site specific data, review papers summarize a variety of site data.

with the dominant vegetation coded for in each polygon of the integrated vegetation complex map (Figure 1). These attributes vary with landscape unit and position along the climatic gradient present in the Canadian Arctic. Lookup tables created in ARCINFO link these attributes and allow the mapping (Figures 1-5) and determination of the areal extent (Tables 2-8) of each attribute category. Lookup tables include the following information: Individual polygon ID, dominant vegetation type, primary, secondary, and tertiary plant functional type (20 categories), percent cover (4 categories), above ground phytomass (5 categories), annual above and belowground primary productivity (5 classes) of the dominant vegetation type, and ancillary data on soils, hydrology, geology, and topography. Information used to create the lookup tables comes from published literature linking plant community composition, degree of vegetation cover, phytomass, and/or productivity in the Arctic (Table 1).

[10] Eleven categories of plant functional types [Walker, 1999] (Figure 2) where chosen which portray patterns strongly related to energy and moisture availability and will be most useful in efforts to model vegetation change related to global climate change [Walker, 2000]. Mapped categories (Table 4) in some cases share similar dominant plant func- tional types but differ in secondary and tertiary plant functional types.

[11] Categories of percent vegetation cover, aboveground plant biomass, and ANPP are modified from Walker [1999]. Correspondence between the vegetation and derived map units and previous literature, particularly the terminology of Bliss [1977, 1988, 1995], Zoltai et al. [1980], Edlund [1990a], Bliss and Matveyeva [1992], and Gould and Walker [1999] have been noted where comparisons have been made in summarizing attributes (Table 3). In our lookup tables, biomass and ANPP categories for each vegetation class vary depending on which bioclimatic zone a polygon occurs in (e.g., Hemiprostrate dwarf shrub tundra occurring in subzone $\mathrm{C}$ will have lower biomass than the same vegetation type occurring in subzone E). The most common biomass and ANPP ranges for mapped vegetation classes are compared with biomass and ANPP estimates from Bliss and Matveyeva [1992] (Table 7). Biomass and ANPP summaries for the Canadian High Arctic (subzones $\mathrm{A}-\mathrm{C}$ ) and Low Arctic (subzones D-E) (Table 8) were calculated by multiplying the area of each biomass or ANPP class by the mean value of that class. We used $2250 \mathrm{~g} \mathrm{~m}^{-2}$, a value lower than the mean, for the highest biomass class (2000-4000 $\left.\mathrm{g} \mathrm{m}^{-2}\right)$ as we estimated that while values range 


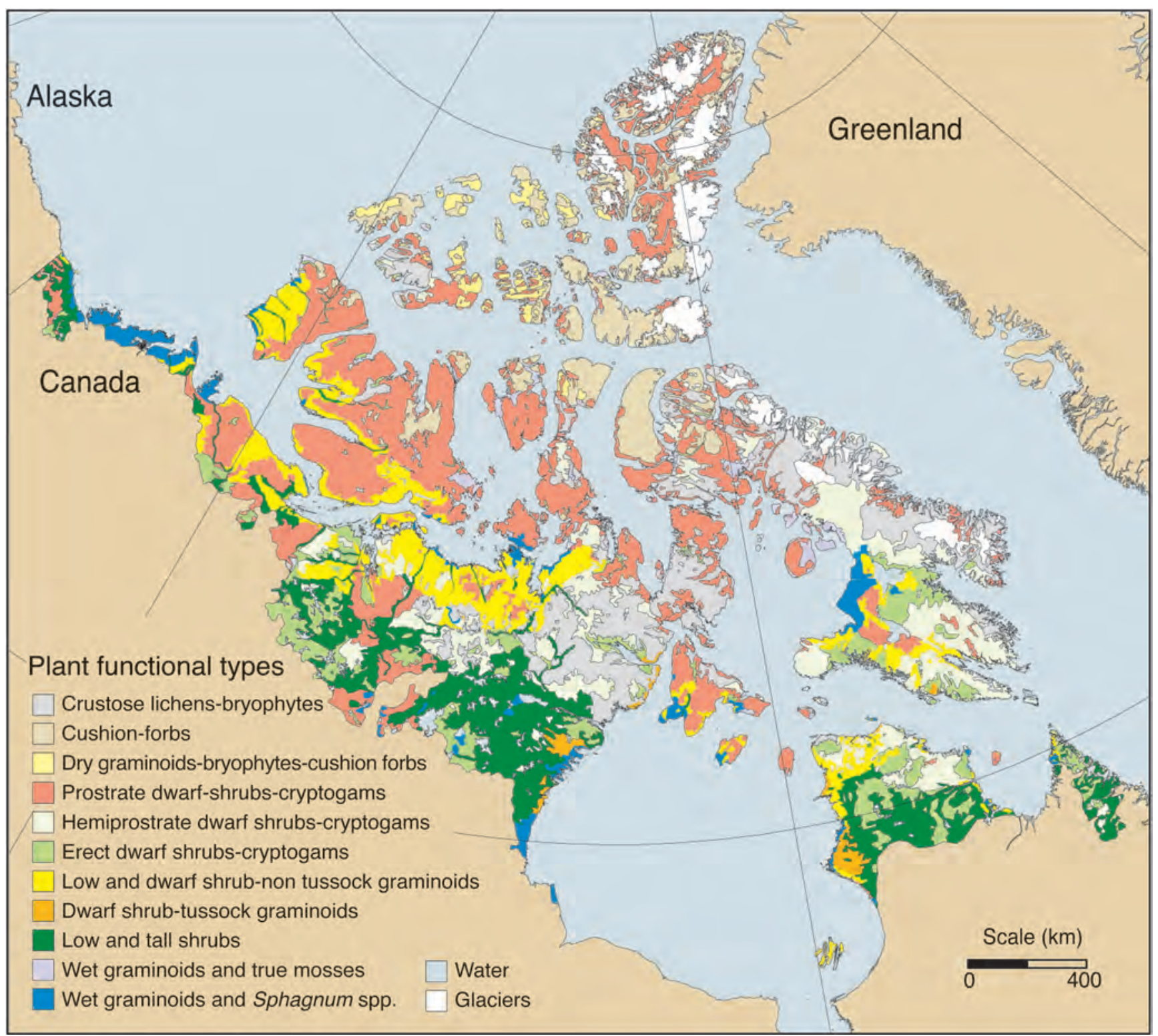

Figure 2. Map of dominant plant functional types in the Canadian Arctic indicating eleven primary plant functional types characteristic of the dominant vegetation within each polygon.

to $4000 \mathrm{~g} \mathrm{~m}^{-2}$ in this class the majority of the vegetation has biomass values closer to the minimum of $2000 \mathrm{~g} \mathrm{~m}^{-2}$.

\subsection{Map Summaries}

[12] We used the GIS database capabilities of ARCINFO to derive summary information on the areal extent of each bioclimatic subzone and vegetation type (Figure 1, Tables 2 and 4), and also grouped these so that we had equivalent categories of Bliss and Matveyeva [1992] and Walker et al. [2001, 2002] when possible (Tables 2, 4, and 8).

\section{Results}

[13] The area mapped encompasses $2.5 \times 10^{6} \mathrm{~km}^{2}$ and includes all of Canada north of the northern limit of trees [Gould et al., 2002a]. It makes up a third of the circumpolar region north of treeline (Table 2) [Bliss and Matveyeva, 1992; Walker et al., 2001, 2002].

\subsection{Bioclimatic Subzones}

[14] Five subzones of the Arctic tundra zone [Edlund, 1990b; Yurtsev, 1994; Elvebakk et al., 1999; Walker, 2000] [Gould et al., 2002a] are depicted overlaying the vegetation map, as well as the delineation of the High and Low Arctic following Bliss and Matveyeva [1992] (Figure 1). Each bioclimatic subzone indicates a shift of roughly $2-3^{\circ} \mathrm{C}$ in mean July temperatures at sea level and accompanying shifts in the northern limits and dominance of particular species, vegetation types, and associated growth forms [Edlund, 1990b; Gould et al., 2002a].

[15] Subzones A-C correspond most closely with the High Arctic of Bliss and Matveyeva [1992] and cover 


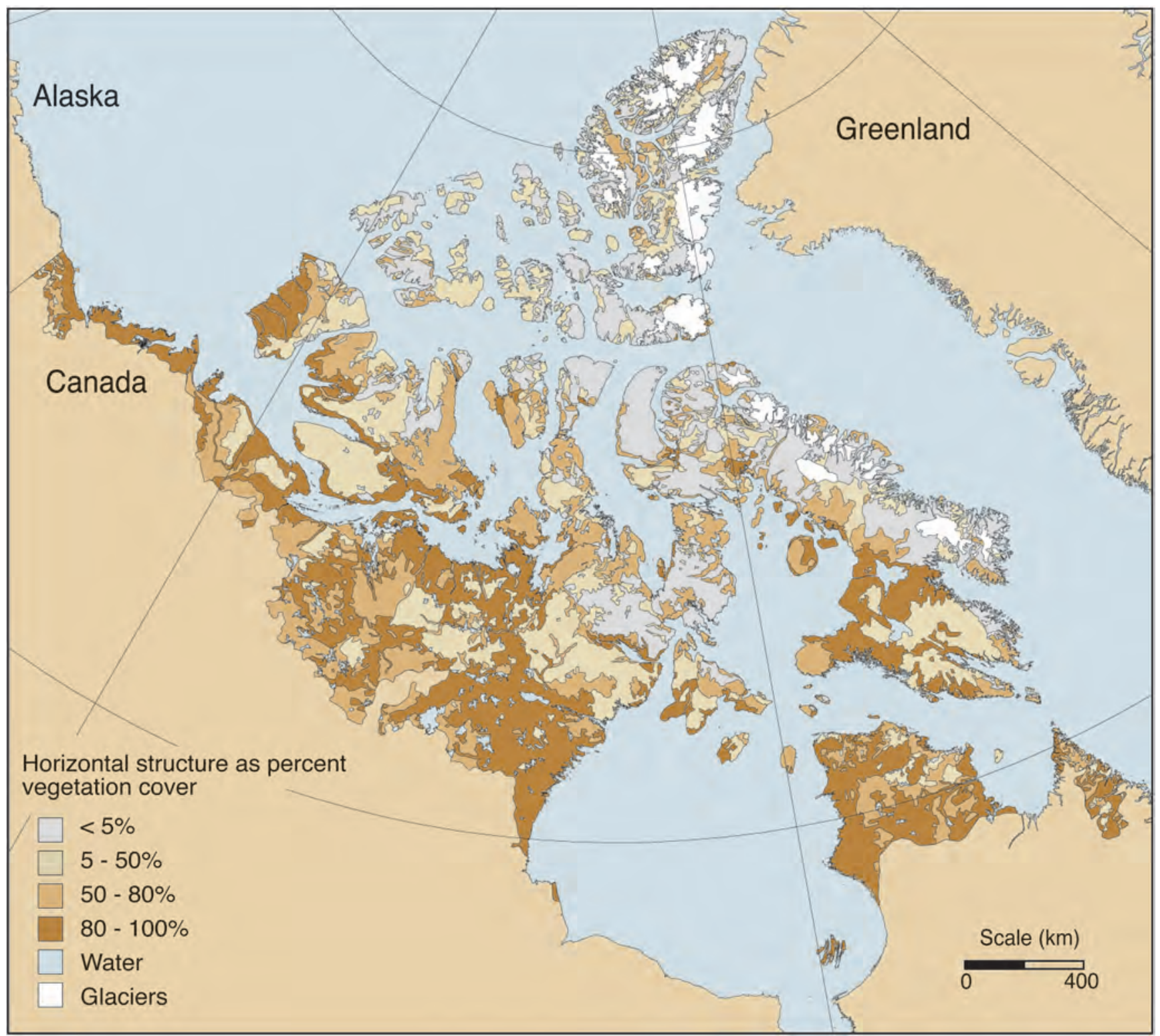

Figure 3. Percent cover of the vegetation canopy. Four categories of percent cover of vegetation typical of each polygon are shown indicating $r$ elative amounts of vegetation cover and bare ground.

roughly half of the Canadian Arctic $\left(1.26 \times 10^{6} \mathrm{~km}^{2}\right)$. Bliss and Matveyeva's [1992] High Arctic extends further south, encompassing all of the Arctic Archipelago, and covers $1.6 \times 10^{6} \mathrm{~km}^{2}$ or $64 \%$ of the Canadian Arctic. Subzones $1-3$ encompass $3.63 \times 10^{6} \mathrm{~km}^{2}$ in the circumpolar region and nearly $50 \%$ of this is in Canada. The circumpolar High Arctic makes over $50 \%$ of the area north of treeline (Table 2) [Bliss and Matveyeva, 1992; Walker et al., 2001, 2002].

[16] Subzones D and E correspond most closely with the Low Arctic of Bliss and Matveyeva [1992] and cover $1.3 \times$ $10^{6} \mathrm{~km}^{2}$ (Table 2). The delineation between Low and High Arctic, and subzones $\mathrm{D}-\mathrm{E}$ and $\mathrm{A}-\mathrm{C}$, separates the area dominated by low and erect (upright growing) dwarf-shrub cover, tussock tundra, and boreal floristic elements (i.e., Low Arctic), from the more northern environments lacking these growth forms and floristic elements (i.e., High Arctic)
[Bliss, 1988; Edlund, 1990b; Bliss and Matveyeva, 1992; Walker, 2000].

[17] Within the High Arctic, subzone $\mathrm{C}$ is the most extensive. Vegetation characteristic of this subzone can be found from $65^{\circ}$ to over $80^{\circ}$ North latitude. Much of subzone $\mathrm{C}$ is dominated by high plateaus and mountains, glaciers, and coarse and strongly calcareous substrates which limit vegetation cover and affect species composition. As a consequence, much of subzones $\mathrm{B}$ and $\mathrm{C}$ share vegetation characteristics typical of subzone B (i.e., cryptogam and cushion forb barrens, and sparsely vegetated Dryas integrifolia prostrate dwarf shrub tundra) [Walker et al., 2001, 2002; Gould et al., 2002a]. Subzone A lacks woody species and is restricted to the fog-bound coasts and low-lying Queen Elizabeth Islands [Edlund and Alt, 1989; Edlund, 1990a, 1990b] [Gould et al., 2002a]. Within the Low Arctic, subzones $\mathrm{D}$ and $\mathrm{E}$ differ in the degree of shrub cover and 


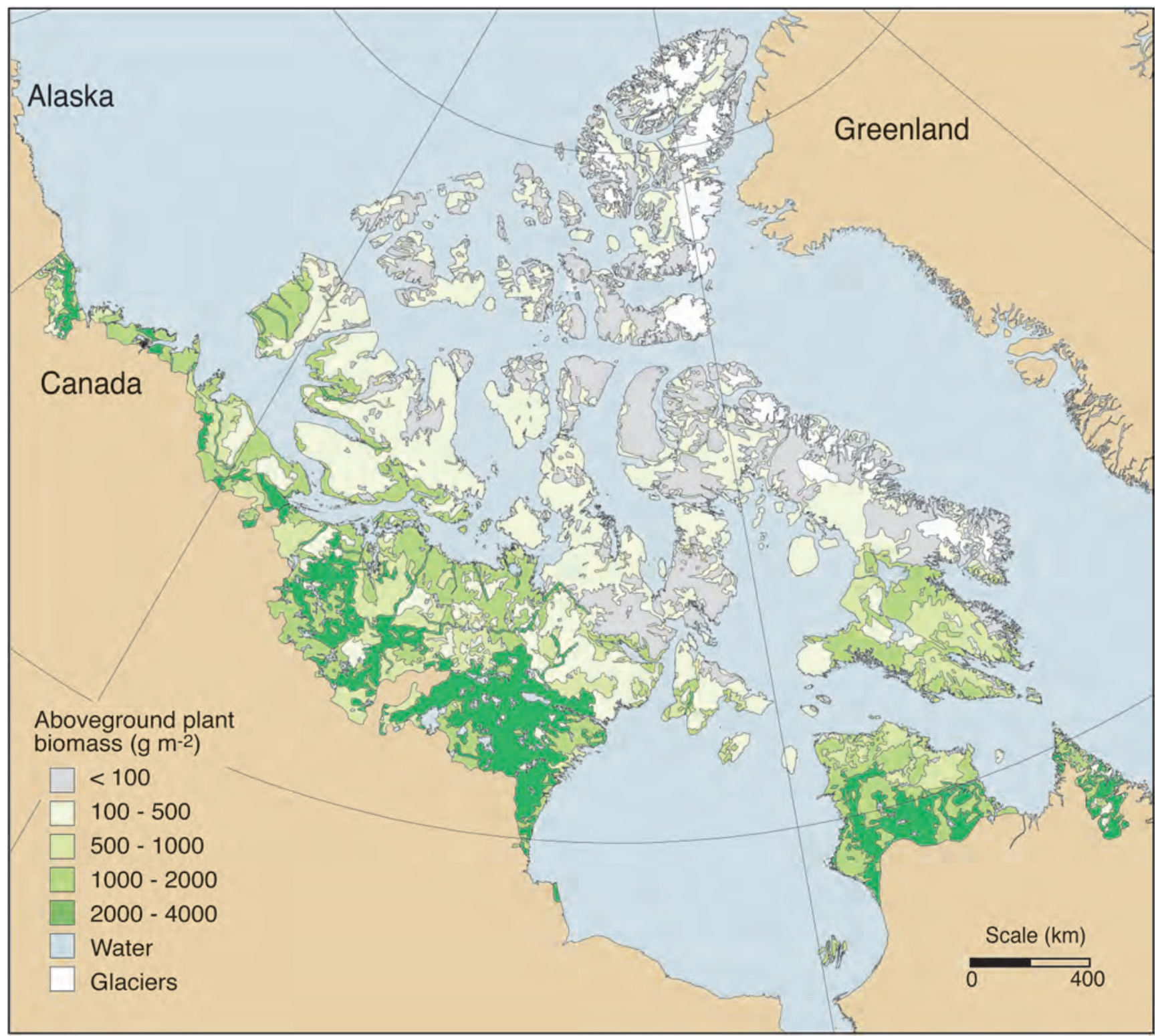

Figure 4. Aboveground plant biomass map indicating patterns of 5 biomass categories (in $\mathrm{g} \mathrm{m}^{-2}$ ) estimated by determining the range of published biomass values for the dominant vegetation type of each polygon in Figure 1.

shrub heights [Gould et al., 2002a]. Subzone D covers $0.679 \times 10^{6} \mathrm{~km}^{2}$ and subzone E covers $0.618 \times 10^{6} \mathrm{~km}^{2}$ (Table 2).

\subsection{Vegetation}

[18] Twenty land cover classes are mapped, including 17 vegetation complexes (Figure 1). Vegetation complexes are characterized by the dominant growth form and plant communities characteristic of each polygon (Table 3) [Gould et al., 2002a]. Variation is primarily controlled by climate (with the suite of potentially present species decreasing with each shift in bioclimatic zones from south to north), substrate chemistry (with acidic and nonacidic substrates strongly affecting species composition), and topographic position (which controls soil moisture). There is considerable variation in soil moisture regimes within each mapped polygon creating a mosaic of dry, mesic, and wet environments along toposequences [Gould et al., 2002a]. However, each polygon represents a landscape unit typically dominated by a single moisture regime (e.g., dry, mesic, wet).

[19] Dry vegetation is dominant on steep hilly terrain, high plateaus, and mountains as these are characterized by welldrained substrates. This includes cryptogam barrens on acidic bedrock landscapes, cushion-forb barrens in the far north on circumneutral and nonacidic substrates, Dryas integrifolia dominated landscapes on nonacidic substrates, and Salix arctica and hemiprostrate heath-lichen vegetation on more acidic substrates (Table 3). Map polygons dominated by dry vegetation cover $36.1 \%$ of the ice-free area $\left(2.353 \times 10^{6} \mathrm{~km}^{2}\right)$ with cryptogam barrens, cushion-forb barrens, and Dryas integrifolia dominated prostrate dwarf-shrub tundra map polygons each covering about $10 \%$ of the map (Table 3 ). 


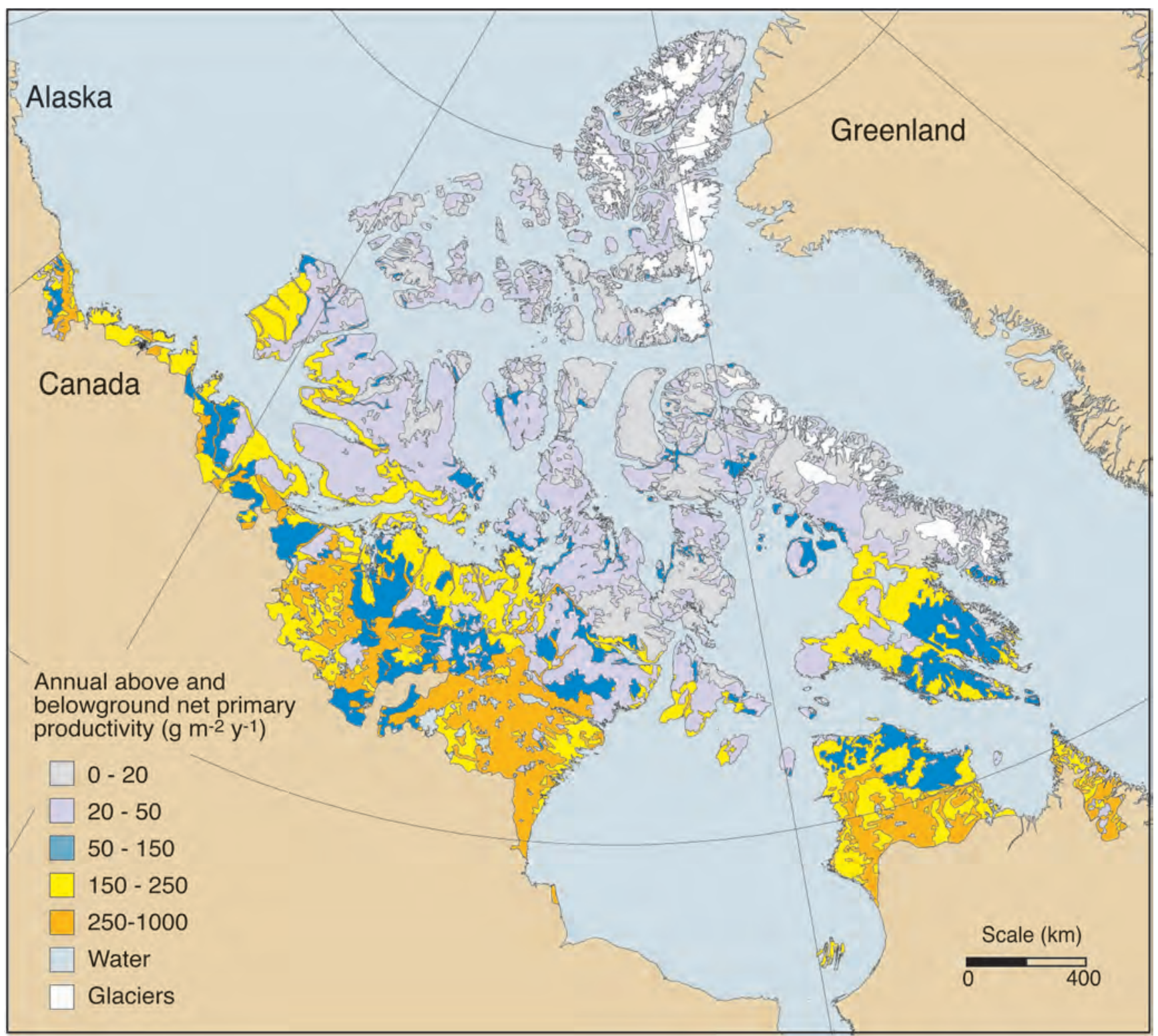

Figure 5. Annual net primary productivity (ANPP) map indicating patterns of annual above and belowground productivity in $\mathrm{g} \mathrm{m}^{-2} \mathrm{yr}^{-1}$. Productivity estimates are based on the range of published productivity values summarized by Bliss and Matveyeva [1992].

[20] Mesic vegetation is typically dominant on inland and coastal rolling plains or low hills. These map polygons are typically a mosaic of dry vegetation on knolls and ridge tops, mesic slopes (dominating), and wet vegetation in low spots, valleys, and lakeshores. It includes a variety of shrubgraminoid communities, with variation in species controlled by climate and substrate. Map polygons dominated by mesic vegetation cover $57.7 \%$ of the mapped area (Table 3 ). The most common mesic vegetation is Dryas dominated prostrate dwarf-shrub-graminoid tundra which covers $16.4 \%$ (Table 3). Vegetation in the low and erect dwarfshrub graminoid map polygons is about $70 \%$ mesic vegetation, and 30\% wet vegetation with increasing sedge and moss cover. The wet component of these complexes comprise about $3.6 \%$ of the ice-free land area.

[21] Wet vegetation can be found in nearly any polygon as drainage is poor on the permafrost and bedrock domi- nated landscapes of the Canadian Arctic. Extensive areas of wet vegetation are typically found in the lowland and coastal plains and consist of graminoids and mosses, with shrub elements on the less saturated areas (Table 3). In the northern arctic, lack of summer warmth limits the species richness and peat development in wetlands. Grasses are dominant in subzones A and B and sedges (e.g., Carex aquatilis var. stans) in subzones 3-5. Polygons mapped as wet vegetation comprise $4.1 \%$ of the ice-free land area (Table 3).

[22] Riparian vegetation is a complex of vegetated wet and mesic areas and floodplain barrens. Most riparian areas are too small to map it this scale. What can be mapped are the larger river valleys with vegetation distinct from the encompassing landscape unit. Riparian areas are more heterogeneous than the surrounding in terms of topography, disturbance, and vegetation [Gould and Walker, 1997]. 
Table 2. Comparison of the areal extent $\left(\times 10^{6} \mathrm{~km}^{2}\right)$ and percent of total of bioclimatic subzones in Canada and the circumpolar region from ${ }^{1}$ (Figure 1), ${ }^{2}$ Bliss and Matveyeva [1992], and ${ }^{3}$ Walker et al. [2001]

\begin{tabular}{|c|c|c|c|c|c|c|c|c|}
\hline & \multicolumn{2}{|c|}{ Canada $^{1}$} & \multicolumn{2}{|c|}{ Canada $^{2}$} & \multicolumn{2}{|c|}{ Circumpolar $^{2}$} & \multicolumn{2}{|c|}{ Circumpolar $^{3}$} \\
\hline & area & percent & area & percent & area & percent & area & percent \\
\hline High Arctic & 1.257 & 49.2 & 1.600 & 64.5 & 3.951 & 52.2 & 3.634 & 51.1 \\
\hline subzone 1 & 0.054 & 2.1 & & & & & & \\
\hline subzone 2 & 0.168 & 6.6 & & & & & & \\
\hline subzone 3 & 1.034 & 40.5 & & & & & & \\
\hline Low Arctic & 1.297 & 50.8 & 0.880 & 35.5 & 3.616 & 47.8 & 3.481 & 48.9 \\
\hline subzone 4 & 0.679 & 26.6 & & & & & & \\
\hline subzone 5 & 0.618 & 24.2 & & & & & & \\
\hline Total & 2.554 & 100 & 2.480 & 100 & 7.567 & 100 & 7.115 & 100 \\
\hline
\end{tabular}

Riparian areas are typically barren with scattered forbs and graminoids in subzones $\mathrm{A}$ and $\mathrm{B}$, and include low to tall shrubs and sedge-moss communities in subzones $\mathrm{C}-\mathrm{E}$. These comprise $2.1 \%$ of the ice-free land area (Table 3 ).

[23] Additional map units include water $(>75 \%$ lake cover and lakes larger than the minimum polygon size) making up $1.8 \%$ of the mapped area, and glaciers $(>75 \%$ year-round ice cover) and Nunatak complexes (ice-free barrens within glaciers) making up $6.0 \%$ of the mapped area (Table 4).

[24] Comparisons of estimates of the areal extent of major vegetation and landcover types from this study can be made with previous estimates by combining mapped units to approximate vegetation types from previous studies [Bliss and Matveyeva, 1992]. The most extensive vegetation type in the Canadian Arctic is the polar semidesert of Bliss [1990] which includes the dry and mesic environments dominated by prostrate dwarf-shrub-graminoid, prostrate dwarf-shrub, and hemiprostrate dwarf-shrub vegetation, in particular by Dryas integrifolia dominated landscapes (40$42 \%$ ) (Table 4). The polar desert of Bliss [1990] and barrens of this study are the next most abundant landcover type, comprising $19-26 \%$ of the region. Tall and low shrub dominated areas comprise $12-18 \%$ of the region, wet sedge vegetation covers $8-11 \%$ of the region, mesic tussock and shrub-graminoid tundra covers $3.5-7 \%$ of the region (Table 4).

\subsection{Derived Maps}

[25] Plant functional types (Figure 2) vary along climatic gradients (latitudinal and elevational) and range from low and tall deciduous shrub in the southern Arctic (mean July temperatures $9-12^{\circ} \mathrm{C}$ ), erect dwarf deciduous and evergreen shrubs (mean July temperatures $7-9^{\circ} \mathrm{C}$ ), prostrate deciduous and evergreen shrubs (mean July temperatures $3-7^{\circ} \mathrm{C}$ ), and cushion forbs and bryophytes beyond the northern limit of woody plants (mean July temperatures $<3{ }^{\circ} \mathrm{C}$ ) [Edlund, 1990b; Gould et al., 2002b].

[26] Spatial patterns of eleven categories of dominant plant functional types closely match the bioclimatic zonation patterns in Figure 1. Cushion forb and cryptogam growth forms are dominant over $20.3 \%$ of the landscape. Prostrate dwarf shrubs (primarily Dryas integrifolia and Salix arctica) cover the largest area (25.9\%). Hemiprostrate and erect dwarf shrubs cover $18.4 \%$ of the region. Shrub graminoid vegetation covers $10.6 \%$ of the region, and low and tall shrubs cover $11.2 \%$ of the region. All shrubs combined cover $60 \%$ of the region, with low and tall shrubs concentrated in subzone $\mathrm{E}$, erect dwarf shrubs in subzone $\mathrm{C}$, and prostrate shrubs in subzones $B$ and $C$, and cryptogams and cushion plants in subzones A and B. Graminoids are common in most landscapes, but graminoid dominated landscapes are restricted to $5.8 \%$ of the region (Figure 2, Table 5).

[27] The canopy cover or horizontal vegetation structure (Figure 3) is controlled by climate (latitudinal and elevational variation), substrate chemistry and texture, and moisture. Percent cover of vegetation decreases with latitude and elevation, and on coarse, extremely calcareous or extremely acidic substrates. Our derived map of vegetation cover estimates $21 \%$ of the mapped area to be barren with less than $5 \%$ percent cover (Table 6). This is a combination of cryptogam barrens found on the acidic Canadian Shield bedrock and on cushion-forb and cryptogam barrens found on the calcareous and coarse textured substrates of the High Arctic. In the High Arctic these regions correspond with the polar desert sensu Bliss [1988]. Over 25\% of the region is estimated to have $5-50 \%$ vegetation cover (polar semidesert sensu Bliss [1988]). This degree of vegetation cover is characteristic of subzones $\mathrm{A}-\mathrm{B}$, i.e., the High Arctic. Approximately $25 \%$ of the region is estimated to have $50-$ $80 \%$ vegetation cover. This is primarily in subzones $\mathrm{C}$ and $\mathrm{D}$ where ridge tops, knolls and well-drained slopes are typically sparsely vegetated $(5-50 \%)$ and gentle slopes and valleys may be completely vegetated. $29 \%$ of the region is estimated to have $<80 \%$ vegetation cover. These areas are concentrated in subzone $\mathrm{E}$ and on low areas in subzone D with suitable substrate and moisture availability (Table 6).

[28] Plant biomass is positively correlated with canopy cover, particularly in the High Arctic [Bliss et al., 1984] where cover is often less than $50 \%$. Most $(86 \%)$ of the aboveground plant biomass for the region is concentrated in the more productive subzones D and E (i.e., the Low Arctic) (Figure 4, Table 8). The areas with the least plant biomass are those with less than $5 \%$ cover (aboveground plant biomass is $<100 \mathrm{~g} \mathrm{~m}^{-2}$ ) [Bliss and Matveyeva, 1992; Walker, 1999]. The areas with the highest plant biomass are the low and tall shrub regions of the low arctic, and riparian tall shrub areas with 2000-4000 $\mathrm{g} \mathrm{m}^{-2}$ (Figure 4, Table 7) [Bliss and Matveyeva, 1992]. Total aboveground plant biomass estimates for both the High and Low Arctic in Canada are somewhat higher than estimates from Bliss and Matveyeva [1992] when their standing crop (above and belowground plant biomass is adjusted to reflect only aboveground biomass) (Tables 7 and 8). The larger High Arctic estimates from Bliss and Matveyeva [1992] reflect 
Table 3. Areal extent $\left(x 10^{6} \mathrm{~km}^{2}\right)$ and percent of total area of vegetation types from the Canadian Arctic Vegetation Map (Figure 1). Roughly equivalent (based on dominant species and composition) or additionally present vegetation types are noted from a variety of sources

\begin{tabular}{|c|c|c|}
\hline Vegetation & area & percent \\
\hline Dry & 0.850 & 36.1 \\
\hline Cryptogam barrens & 0.258 & 11.0 \\
\hline $\begin{array}{l}\text { Hierochloë alpina-Rhizocarpon geographicum comm. [Gould and Walker, 1999], } \\
\text { rock-lichen type [Zoltai et al., 1980], cushion plant-cryptogam semidesert [Bliss, 1997], } \\
\text { cryptogamic and herb barrens [Edlund, 1990a], rock-barrens [Thompson, 1980]. }\end{array}$ & & \\
\hline $\begin{array}{l}\text { Cushion-forb barrens } \\
\text { Papaveretum dahlianae [Dierssen, 1996], polar desert [Bliss, 1995], Luzula and Purple } \\
\text { saxifrage barrens [Edlund, 1990a]. }\end{array}$ & 0.225 & 9.6 \\
\hline $\begin{array}{l}\text { Prostrate dwarf-shrub tundra (nonacidic) } \\
\text { Carici-Dryadetum intregrifoliae [Daniëls, 1982], cushion plant-cryptogam semidesert } \\
\text { [Bliss, 1997], lichen-dryas plateau [Thompson, 1980]. }\end{array}$ & 0.226 & 9.6 \\
\hline $\begin{array}{l}\text { Prostrate dwarf-shrub-lichen tundra (acidic) } \\
\text { Salix arctica-Dryas integrifolia comm. [Gould et al., 2001b], dwarf shrub heath tundra } \\
\text { [Bliss, 1997], Dryas-Salix tundra [Edlund, 1990a], willow-lichen meadow [Sheard and Geale, 1982]. }\end{array}$ & 0.039 & 1.7 \\
\hline Erect dwarf-shrub-lichen tundra (acidic) & 0.102 & 4.3 \\
\hline
\end{tabular}

Arctous alpinus-Betula glandulosa comm. [Gould and Walker, 1999], dwarf shrub heath

type [Zoltai et al., 1980], dwarf shrub heath [Bliss, 1997].

Mesic

Graminoid-forb

Prostrate dwarf-shrub-graminorssen, 1996], cryptogan

Carici-Dryadetum intregrifoliae [Daniëls, 1982], cushion plant-cryptogam semidesert

[Bliss, 1997], Dryas-Salix tundra [Edlund, 1990a]. Lichen-cushion plant-dwarf shrub

[Muc et al., 1989].

Hemiprostrate dwarf-shrub tundra (acidic)

Saliceto-Cassiopetum tetragonae [sensu Daniëls et Fredskild in Fredskild, 1998], dwarf

shrub heath type [Zoltai et al., 1980], lichen-heath tundra [Edlund, 1976], dwarf shrub heath tundra [Bliss, 1998].

Erect dwarf-shrub-graminoid tundra (nonacidic)

Salix lanata-Kobresia-Carex aquatilis-Arctogrostis latifloia comm. [Schaefer and

Mseeier, 1993] Carex atrofusca-Salix lanata ssp. richardsonii, Equisetum arvense-Salix

lanata ssp. richardsonii comms. [Gould and Walker, 1999], Sedge-dwarf shrub tundra

[Bliss, 1995], Dryado integrifoliae-Caricetum bigelowii [Walker et al., 1994], willow

hummocks [Thompson, 1980], moist sedge meadow [Rieznicek and Svoboda, 1982].

Erect dwarf-shrub tundra (acidic)

Betulo-ledetum decumbentis [Lambert, 1968], Hierochloë alpina-Betula glandulosa comm.

[Gould and Walker, 1999], dwarf shrub heath type [Zoltai et al., 1980], lichen-heath tundra [Edlund, 1976], dwarf shrub heath tundra [Bliss, 1988].

Low shrub-graminoid

Dryado integrifoliae-Caricetum bigelowii, Sphagno-Eriophoretum vaginati [Walker et al., 1994], Saussuria angustifolia-Dryas integrifolia comm. [Gould and Walker, 1999], cottongrass-tussock tundra [Edlund, 1976], cottongrass-low shrub heath [Bliss, 1988].

Low shrub tundra

Low shrub tundra [Bliss, 1988], low shrub heath type [Zoltai et al., 1980], Hierochloë

alpina-Betula glandulosa comm. [Gould and Walker, 1999], shrub tundra [Edlund, 1976].

Wet

Grass-moss tundra

Graminoid-moss tundra-High Arctic [Bliss, 1988], Grass meadow [Edlund, 1990a],

Alopecuris alpinus-Campylium arcticum comm. [Gould et al., 2001b].

Sedge-moss tundra

Wet sedge meadow [Edlund, 1976; 1990a, 1990b], Graminoid-moss tundra-High Arctic

[Bliss, 1988], Carex aquatilis var. stans-Drepanocladus revolutum comm. [Gould et al., 2001b],

Carex aquatilis-Eriophorum triste comm. [Bergeron and Svoboda, 1989].

Low shrub-sedge-moss tundra

Graminoid moss tundra-Low Arctic [Bliss, 1988], Wet sedge meadow [Edlund, 1976],

Sedge meadow type [Zoltai et al., 1980], Salix pulchra-Carex aquatilis and

Carex aquatilis-C. chordorrhiza comms. [Gould and Walker, 1999], wet sedge meadow

[Rieznicek and Svoboda, 1982].

\section{Riparian}

Forb-graminoid barrens

Herb barrens [Edlund, 1990a], Chamaenerietum latifolii [Böcher, 1933], Papaveretum

dahlianae [Dierssen, 1996], polar desert [Bliss, 1995], Cerastium regelii-Papaver

dahliana comm. [Gould et al., 2001b].

Low shrub-graminoid-forb complex

Chamaenerietum latifolii [Böcher, 1933], Epilobium latifolium-Salix alaxensis and Salix pulchra-Carex aquatilis comms. [Gould and Walker, 1999], high shrub type [Zoltai et al., 1980], tall shrub tundra [Bliss, 1988]. 
Table 4. Comparison of estimates of areal extent $\left(\times 10^{6} \mathrm{~km}^{2}\right)$ of major Arctic vegetation and landcover types in the Canadian and Circumpolar Arctic

\begin{tabular}{|c|c|c|c|c|c|c|c|c|c|}
\hline \multirow[b]{2}{*}{ land cover } & \multicolumn{2}{|c|}{ from Figure 1} & \multicolumn{4}{|c|}{ from Bliss and Matveyeva [1992] } & \multicolumn{3}{|c|}{ from Walker et al. [2001] } \\
\hline & $\begin{array}{c}\text { area } \\
\text { (Canada) } \\
\end{array}$ & percent & vegetation type & $\begin{array}{c}\text { area } \\
\text { (Canada) } \\
\end{array}$ & percent & $\begin{array}{c}\text { area } \\
\text { (circumpolar) }\end{array}$ & percent & $\begin{array}{c}\text { area } \\
\text { (circumpolar) }\end{array}$ & percent \\
\hline $\begin{array}{l}\text { prostrate dwarf-shrub-graminoid, } \\
\text { prostrate dwarf-shrub, and hemiprostrate dwarf-shru }\end{array}$ & $\mathrm{ub} \quad 1.03$ & 40.3 & semidesert & 1.046 & 42.2 & 1.363 & 18.0 & - & - \\
\hline barrens & 0.488 & 19.1 & polar desert & 0.64 & 25.8 & 0.847 & 11.2 & - & - \\
\hline tall and low shrub & 0.454 & 17.8 & tall and low shrub & 0.29 & 11.7 & 1.456 & 19.2 & - & - \\
\hline wet sedge $^{\mathrm{a}}$ & 0.197 & 7.7 & mire (wet sedge) & 0.272 & 11.0 & 1.012 & 13.4 & - & - \\
\hline low and erect dwarf-shrub-graminoid ${ }^{\mathrm{a}}$ & 0.184 & 7.2 & $\begin{array}{l}\text { tussock, sedge- } \\
\text { dwarf shrub }\end{array}$ & 0.088 & 3.5 & 0.922 & 12.2 & - & - \\
\hline glaciers & 0.153 & 6.0 & & 0.144 & 5.8 & & 26.0 & 2.034 & 28.6 \\
\hline ice-free land & 2.353 & 92.2 & & 2.336 & 94.2 & 5.600 & 74.0 & 5.081 & 71.4 \\
\hline lake polygons & 0.047 & 1.8 & & - & - & - & - & - & - \\
\hline total & 2.553 & 100.0 & & 2.480 & 100.0 & 7.567 & 100.0 & 7.115 & 100.0 \\
\hline
\end{tabular}

${ }^{a}$ low and erect dwarf-shrub vegetation types contain up to $30 \%$ wet sedge meadow and area estimates have been split into this group (70\%) and the wet sedge category $(30 \%)$.

differences in the areal extent of the High Arctic sensu Bliss [1988] versus the sum of areas of subzones 1-3 (Table 2).

[29] Annual net primary productivity (ANPP) is also strongly related to bioclimatic zonation with $87 \%$ of the total above and belowground ANPP produced in subzones D and E (i.e., the Low Arctic) (Figure 5, Tables 7 and 8). The least productive areas are the cryptogam and cushion-forb barrens with NPP of $<20 \mathrm{~g} \mathrm{~m}^{-2} \mathrm{yr}^{-1}$ and the most productive areas are the Low Arctic riparian shrub communities with NPP ranging from 250 to $1000 \mathrm{~g} \mathrm{~m}^{-2} \mathrm{yr}^{-1}$. Summaries of ANPP derived from the vegetation map (Figure 1) and from the literature [Bliss and Matveyeva, 1992] show similar patterns for the High Arctic, Low Arctic, and total Arctic area in Canada (Tables 7 and 8).

\section{Discussion}

[30] The new maps and analyses presented here confirm both Bliss' [1990] interpretation of the Canadian Arctic as a mosaic of major vegetation types controlled by topography and substrate and Edlund's [1990a, 1990b] view of the region as a series of vegetation zones controlled by climate. Climate plays the major role in limiting the pool of species available for establishment and growth in a region, with mean summer energy availability (most readily available as mean July temperature measures and estimates) being the

Table 5. Areal extent $\left(x 10^{6} \mathrm{~km}^{2}\right)$ and percent of total of dominant plant functional types

\begin{tabular}{lcr}
\hline \multicolumn{1}{c}{ Dominant functional type } & area & percent \\
\hline Crustose lichens-bryophytes & 0.345 & 13.6 \\
Cushion-forbs & 0.168 & 6.7 \\
Dry graminoids-bryophyte-cushion forbs & 0.041 & 1.6 \\
Prostrate dwarf shrubs-cryptogams & 0.650 & 25.7 \\
Hemiprostrate dwarf shrubs-cryptogams & 0.265 & 10.5 \\
Erect dwarf shrubs-cryptogams & 0.201 & 7.9 \\
Low and dwarf shrub-non tussock graminoids & 0.248 & 9.8 \\
Dwarf shrub-tussock graminoids & 0.020 & 0.8 \\
Low and tall shrubs & 0.284 & 11.2 \\
Wet graminoids-true mosses & 0.041 & 1.6 \\
Wet graminoids-true mosses-Spahgnum spp. & 0.066 & 2.6 \\
Water & 0.047 & 1.9 \\
Glaciers & 0.153 & 6.1 \\
Total & $\mathbf{2 . 5 3}$ & $\mathbf{1 0 0 . 0}$ \\
\hline
\end{tabular}

critical climatic element controlling potential plant species composition [Rannie, 1986; Edlund and Alt, 1989; Walker, 2000]. Mean July temperature isolines are not linearly correlated with latitude in the Canadian Arctic. Hudson Bay has a summer cooling effect over the eastern Low Arctic, the permanent ice pack has a cooling effect over the Queen Elizabeth Islands, and topography, landmass, and open ocean have warming effects over eastern Ellesmere and western Axel Heiberg and Western Melville Islands [Edlund, 1990b]. Vegetation responds to these complex patterns of summer warmth creating the bioclimatic patterns illustrated in Figure 1. Within this framework of climatic patterns, variation in vegetation composition and degree of vegetation cover are a function of landscape patterns related to geology and topography. Extremely calcareous and alkaline, acidic, coarse textured, and rubble and bedrock dominated landscapes support little vegetation cover in a variety of subzones; more neutral, mesic, and wet conditions support greater vegetation cover [Bliss, 1990]. The mosaic of vegetation linked to geologic and topographic patterns is readily evident in satellite imagery of the Canadian Arctic and in the maps presented here. One type of description (i.e., zones versus mosaic) need not replace another as long as authors are explicit in their terminology.

[31] The utility of linking spatial patterns of vegetation cover (Figure 1) with published vegetation descriptions (Table 3 ) is that it increases the amount of vegetation and ecological information available about each of the mapped units. The major difficulties in mapping the Canadian Arctic are that 1) there are few detailed vegetation descriptions for the majority of mapped polygons, and 2) all polygons represent a mix of plant communities at this scale, and determining which communities, even when well-described, are dominant in a particular polygon is difficult from much

Table 6. Areal extent $\left(\times 10^{6} \mathrm{~km}^{2}\right)$ and percent of total of horizontal vegetation canopy cover classes (Figure 3)

\begin{tabular}{lcr}
\hline Coverage & area & percent \\
\hline$<5 \%$ & 0.494 & 21.0 \\
$5-50 \%$ & 0.593 & 25.2 \\
$50-80 \%$ & 0.583 & 24.8 \\
$>80 \%$ & 0.683 & 29.0 \\
Total & $\mathbf{2 . 3 5 3}$ & $\mathbf{1 0 0 . 0}$ \\
\hline
\end{tabular}


Table 7. Range of aboveground biomass and ANPP values for vegetation classes (Figure 1) and aboveground biomass ${ }^{*}$ and productivity values from Bliss and Matveyeva [1992]

\begin{tabular}{|c|c|c|c|c|c|}
\hline \multirow[b]{2}{*}{ Vegetation classes (Figure 1) } & \multirow[b]{2}{*}{$\begin{array}{c}\text { Aboveground } \\
\text { biomass }\left(\mathrm{g} \mathrm{m}^{-2}\right)\end{array}$} & \multirow[b]{2}{*}{$\begin{array}{c}\text { ANPP } \\
\left(\mathrm{g} \mathrm{m}^{-2} \mathrm{y}^{-1}\right)\end{array}$} & \multicolumn{3}{|c|}{ from Bliss and Matveyeva [1992] } \\
\hline & & & vegetation type & $\begin{array}{c}\text { Aboveground } \\
\text { biomass }\left(\mathrm{g} \mathrm{m}^{-2}\right)\end{array}$ & $\begin{array}{c}\text { ANPP } \\
\left(\mathrm{g} \mathrm{m}^{-2} \mathrm{y}^{-1}\right)\end{array}$ \\
\hline $\begin{array}{l}\text { Cushion-forb barrens, } \\
\text { Forb-graminoid barrens, Cryptogam barrens. }\end{array}$ & $<100$ & $<20$ & polar desert & 18 & 0.7 \\
\hline $\begin{array}{l}\text { Graminoid forb tundra, Grass-moss tundra, } \\
\text { Sedge-moss tundra, Prostrate dwarf shrub tundra, } \\
\text { Prostrate dwarf shrub-lichen tundra, }\end{array}$ & & & & & \\
\hline Prostrate dwarf shrub graminoid tundra, & & & high arctic mires & 112 & 60.0 \\
\hline Hemiprostrate dwarf shrub tundra, & & & low arctic mires & 217 & 70.0 \\
\hline Hemiprostrate dwarf shrub-lichen tundra. & $100-500$ & $20-50$ & high arctic semidesert & 385 & 25.0 \\
\hline $\begin{array}{l}\text { Hemiprostrate dwarf shrub tundra, } \\
\text { Hemiprostrate dwarf shrub-lichen tundra, Low } \\
\text { shrub-sedge-moss tundra, Low shrub-graminoid- } \\
\text { forb complex, Sedge-moss tundra. }\end{array}$ & $500-1000$ & $50-150$ & low arctic semidesert & 735 & 28.0 \\
\hline $\begin{array}{l}\text { Erect dwarf shrub tundra, } \\
\text { Erect dwarf shrub-graminoid tundra, } \\
\text { Low shrub-graminoid tundra, Sedge-moss tundra, } \\
\text { Low shrub-graminoid-forb complex. }\end{array}$ & $1000-2000$ & $150-250$ & tussock, sedge-dwarf shrub & 1850 & 125.0 \\
\hline $\begin{array}{l}\text { Low shrub tundra, } \\
\text { Low shrub-graminoid-forb complex. }\end{array}$ & $2000-4000$ & $250-1000$ & $\begin{array}{l}\text { low shrub } \\
\text { tall shrub }\end{array}$ & $\begin{array}{l}2067 \\
3867\end{array}$ & $\begin{array}{l}125.0 \\
100.0\end{array}$ \\
\hline
\end{tabular}

of the literature. Previous large-scale vegetation maps are useful in interpreting the AVHRR imagery. These are most useful when accompanied by detailed vegetation descriptions and references to vegetation literature. While there are many areas of the Canadian Arctic lacking in detailed vegetation description there was much excellent work on which to base our map. A reference library of over 1000 published vegetation records for Canada has been incorporated into the GIS database for the map. New studies and information can be periodically reviewed and incorporated into the GIS database, and revised maps could be produced without duplicating the entire mapping effort.

[32] The derived maps have the same limitations as the vegetation map in terms of lack of ground information, especially measures of plant biomass and productivity. The values presented reflect measured values in dominant vegetation types and the real percentage of these dominant vegetation types within any one polygon is difficult to measure. Nevertheless, the derived maps present new estimates based on interpretation of recent satellite images of the region. Estimated values fall within the ranges of previous published estimates, and the patterns portrayed represent the most explicit spatial representation of these ecosystem attributes to date.

[33] The plant functional type map is in essence a simplified vegetation map. It will be useful in modeling shifts in plant functional types related to global climate change. The functional types are consistent with circumpolar mapping and modeling efforts [Walker, 2000]. Current patterns and potential changes are important in terms of climate and snow cover feedbacks [Sturm et al., 2001], and wildlife habitat. The vegetation cover and potential changes in degree of cover are important in land cover change analyses related to climate change, vegetationclimate feedbacks, and wildlife habitat. Plant biomass and productivity estimates are useful indicators of wildlife habitat quality, in regional and global carbon budget estimates, and in modeling response of ecosystem properties to climate change.

\section{Conclusion}

[34] We feel the combination of satellite image analysis and mapping with detailed field-measured vegetation composition and ecosystem property information is a powerful tool for spatial and temporal analyses and extrapolation of information. Additional descriptive field work linked to mapped vegetation types will provide more precise estimates of mapped properties and the ability to map additional properties. These might include specific wildlife

Table 8. Comparison of estimates for aboveground phytomass in gigagrams (Gg: $10^{12} \mathrm{~g}$ ) and above and belowground annual net primary productivity (ANPP in $\mathrm{Gg} \mathrm{y}^{-1}$ ) for the High Arctic (subzones 1, 2, and 3), the Low Arctic (subzones 4 and 5), and the Canadian Arctic. Values derived from Figures 4 and 5 reflect the mean value multiplied by the areal coverage for each category

\begin{tabular}{lcc}
\hline & $\begin{array}{c}\text { from } \\
\text { Figures 4 and 5 5 }\end{array}$ & $\begin{array}{c}\text { from Biss [1988] } \\
\text { and Bliss and } \\
\text { Matveyeva [1992] }\end{array}$ \\
\hline Aboveground phytomass (total aboveground standing crop) \\
High Arctic (subzones 1-3) & 213.86 & 299.51 \\
Low Arctic (subzones 4 and 5) & 1285.31 & 1086.76 \\
Total & 1499.18 & 1386.27 \\
& & \\
Above and belowground ANPP (total annual growth) \\
High Arctic \\
Low Arctic \\
Total \\
\hline
\end{tabular}


habitat, $\mathrm{CO}_{2}$ or $\mathrm{CH}_{4}$ flux patterns linked to vegetation types, total carbon patterns and amounts. Future development of the GIS database used in creating these maps and summaries is encouraged, as is collaboration with vegetation and wildlife ecologists, and Nunavut land management boards.

[35] Acknowledgments. This project was funded by the National Science Foundation Arctic Transitions in the Land-Atmosphere System (ATLAS) project (OPP-9732076) with assistance from an NSF Postdoctoral Fellowship in Science Education and the International Institute for Tropical Studies, USDA Forest Service. We thank all the members of the CAVM project.

\section{References}

Abbe, E. C., Botanical results of the Grenfell-Forbes Northern Labrador Expedition, 1931, Rhodora, 448, 102-160, 1936.

Bergeron, J.-F., and J. Svoboda, Plant communities of Sverdrup Pass, Ellesmere Island, N.W.T., Musk-ox, 37, 76-85, 1989.

Beringer, J., N. J. Tapper, I. McHugh, F. S. Chapin III, A. H. Lynch, M. C. Serreze, and A. Slater, Impact of Arctic treeline on synoptic climate, Geophys. Res. Lett., 28, 4247, 2001.

Beschel, R. E., Botany: And some remarks on the history of vegetation and glacierization, in Jacobsen-McGill Arctic Research Expedition to Axel Heiberg Island. Preliminary Report 1959-1960, edited by B. S. Miller, pp. 179-199, McGill Univ., Montreal, 1961.

Bliss, L. C., Truelove Lowland, Devon Island, Canada: A High Arctic Ecosystem, pp. 714, Univ. of Alberta Press, Edmonton, Alberta, 1977.

Bliss, L. C., Arctic ecosystems: Their structure, function and herbivore carrying capacity, in Grazing Research at Northern Latitudes, edited by O. Gudmundsson, pp. 5-25, Plenum, New York, 1986.

Bliss, L. C., Arctic tundra and polar desert biome, in Terrestrial Vegetation of North America, edited by M. G. Barbour and W. D. Billings, pp. 1-32, Cambridge Univ. Press, New York, 1988.

Bliss, L. C., High Arctic ecosystems: How they develop and are maintained, in Canada's Missing Dimension: Science and History in the Canadian Arctic Islands, edited by C. R. Harrington, pp. 350-383, Can. Mus. of Nat., Ottawa, Canada, 1990.

Bliss, L. C., Northern polar ecosystems, in Encyclopedia of Environmental Biology, pp. 587-623, Academic, San Diego, Calif., 1995.

Bliss, L. C., Arctic ecosystems of North America, in Polar and Alpine Tundra, edited by F. E. Wielgolaski, pp. 551-683, Elsevier Sci., New York, 1997

Bliss, L. C., and N. V. Matveyeva, Circumpolar arctic vegetation, in Arctic Ecosystems in a Changing Climate: An Ecophysiological Perspective, edited by F. S. Chapin III et al., pp. 59-89, Academic, San Diego, Calif., 1992.

Bliss, L. C., and J. Svoboda, Plant communities and plant production in the western Queen Elizabeth Islands, Holarctic Ecol., 7, 325-344, 1984.

Bliss, L. C., and R. W. Wein, Plant community responses to disturbance in the western Canadian arctic, Can. J. Bot., 50, 1097-1109, 1972

Bliss, L. C., G. M. Courtin, D. L. Pattie, R. R. Riewe, D. W. A. Whitfield, and P. Widden, Arctic tundra ecosystems, in Annual Review of Ecology and Systematics, edited by R. F. Johnston, P. W. Frank, and C. D. Michener, pp. 359-399, Annual Rev., Palo Alto, Calif., 1973.

Bliss, L. C., J. Svoboda, and D. I. Bliss, Polar deserts, their plant cover and plant production in the Canadian High Arctic, Holarctic Ecol., 7, $305-$ 324, 1984.

Böcher, T. W., Studies on the vegetation of the east coast of Greenland, Medd. Groenl. Biosci., 104, 56 pp., 1933.

Braun-Blanquet, J., Plant Sociology: The Study of Plant Communities, 439 pp., Hafner, Old Tappan, N. J., 1965.

Callaghan, T. V., N. Matveyeva, Y. Chernov, and R. Brooker, Arctic ecosystems, Encycl. Biodivers., 1, 231-247, 2001.

Chapin, F. S., III, and C. Körner, Arctic and Alpine Biodiversity: Patterns, Causes and Ecosystem Consequences, Springer-Verlag, New York, 1995.

Chernov, Y. I., and N. V. Matveyeva, Chapter 16: Arctic ecosystems in Russia, in Polar and Alpine Tundra, edited by F. E. Wielgolaski, pp. 361-507, Elsevier Sci., New York, 1997.

Cihlar, J., and J. Beaubien, Land Cover of Canada, Nat. Resour. Can., Ottawa, Canada, 1998

Conservation of Arctic Flora and Fauna (CAFF), Atlas of Rare Circumpolar Endemic Arctic Vascular Plants, U.S. Fish and Wildl. Serv., Anchorage, Alaska, 1996.

Daniëls, F. J. A., Vegetation of the Angmagssalik District Southeast Greenland, 3, Epilithic macrolichen communities, Medd. Groenl., 198(3), 32, 1976.
Daniëls, F. J. A., Vegetation of the Angmagssalik District, Southeast Greenland, Shrub, 4, Dwarf shrub and terricolous lichens, Medd. Groenl. Biosci., 10, 1-78, 1982 .

Dierssen, K., Vegetation Nordeuropas, 838 pp., Ulmer, Stuttgart, 1996.

Edlund, S., Vegetation of the North-Central District of Keewatin Northwest Territories, Geol. Surv. of Can., Ottawa, Canada, 1976.

Edlund, S. A., Vegetation of Lougheed Island, District of Franklin, in Current Research, Part A, Paper 80-1A, pp. 329-333, Geol. Surv. of Can., Ottawa, Canada, 1980.

Edlund, S. A., Bioclimatic zonation in a High Arctic region: Central Queen Elizabeth Islands, in Current Research, Part A, pp. 381-390, Geol. Surv. of Can., Ottawa, Canada, 1983.

Edlund, S. A., Vegetation, Central Queen Elizabeth Islands, District of Franklin, Northwest Territories, Map 1755A, Geol. Surv. of Can., Ottawa, Canada, 1990a.

Edlund, A., Bioclimatic zones in the Canadian Arctic Archipelago, in $\mathrm{Ca}$ nada's Missing Dimension: Science and History in the Canadian Arctic Islands, edited by C. R. Harrington, pp. 421-441, Can. Mus. of Nat., Ottawa, Canada, 1990b.

Edlund, S. A., and B. T. Alt, Regional congruence of vegetation and summer climate patterns in the Queen Elizabeth Islands, Northwest Territories, Canada, Arctic, 42(1), 3-23, 1989.

Elvebakk, A., R. Elven, and V. Y. Razzhivin, Delimitation, zonal and sectorial subdivision of the Arctic for the Panarctic Flora Project, in The Species Concept in the High North-A Panarctic Flora Initiative, edited by I. Nordal and V. Y. Razzhivin, pp. 375-386, Nor. Acad. of Sci. and Lett., Oslo, 1999.

Epp, H., and S. Matthews, Remote sensing of arctic environments: Introduction, Arctic, 44, (iii), 1991.

Eugster, W., et al., Land-atmosphere energy exchange in Arctic tundra and boreal forest: Available data and feedbacks to climate, Global Change Biol., 6(Suppl. 1), 84-115, 2000.

Fernald, M. L., A botanical expedition to Newfoundland and Labrador, Rhodora, 13, 108-162, July 1911.

Gilmanov, T. G., and W. C. Oechel, New estimates of organic matter reserves and net primary productivity of the North American tundra ecosystems, J. Biogeogr., 22, 723-741, 1995.

Gould, W. A., Remote sensing of vegetation, plant species richness, and regional diversity hotspots, Ecol. Appl., 10, 1861-1870, 2000.

Gould, W. A., and M. D. Walker, Landscape-scale patterns in plant richness along an arctic river, Can. J. Bot., 75, 1748-1765, 1997.

Gould, W. A., and M. D. Walker, Plant communities and landscape diversity along a Canadian Arctic river, J. Veg. Sci., 10, 537-548, 1999.

Gould, W. A., D. A. Walker, and D. Biesboer, Combining research and education: Bioclimatic zonation along a Canadian Arctic transect, Artic, in press, 2002a.

Gould, W. A., D. A. Walker, M. Raynolds, H. Maier, S. Edlund, and S. Zoltai, Canadian Arctic vegetation mapping, Int. J. Remote Sens., 23, 4597-4609, 2002b.

Henry, G. H. R., Environmental influences on the structure of sedge meadows in the Canadian High Arctic, Plant Ecol., 134, 119-129, 1998.

Komárková, V., and P. J. Webber, Two Low Arctic vegetation maps near Atkasook, Alaska, Arct. Alp. Res., 12, 447-472, 1980.

Lambert, J., The ecology and successional trends of tundra plant communities in the Low Arctic subalpine zone of the Richardson and British Mountains of the Canadian western Arctic, Ph.D. thesis, Univ. of British Columbia, Vancouver, 1968.

Muc, M., B. Freedman, and J. Svoboda, Vascular plant communities of a polar oasis at Alexandra Fiord (79 N), Ellesmere Island, Canada, Can. J. Bot., 67, 1126-1136, 1989.

Oechel, W. C., T. Callaghan, T. Gilmanov, J. I. Holten, B. Maxwell, U. Molau, and B. Sveinbjörnsson, Global Change and Arctic Terrestrial Ecosystems. Springer-Verlag, New York, 1997.

Porsild, A. E., Flora of the Northwest Territories, in Canada's Western Northland, edited by J. O. Patenaude, pp. 130-141, I.S.O., Ottawa, 1937.

Rannie, W. F., Summer air temperature and number of vascular species in arctic Canada, Arctic, 39(2), 133-137, 1986.

Raup, H. M., The distribution and affinities of the vegetation of the Athabasca-Great Slave Lake region, Rhodora, 32, 187-208, 1930

Raynolds, M., and C. Markon (Eds.), Fourth International Circumpolar Arctic Vegetation Mapping Workshop, U.S. Geol. Surv., Reston, VA, and Russ. Acad. Sci., Moscow, 2001.

Reeburgh, W. S., J. Y. King, S. K. Regli, G. W. Kling, N. A. Auerbach, and D. A. Walker, A CH4 emission estimate for the Kuparuk River basin, Alaska, J. Geophys. Res., 103, 29,005-29,014, 1998.

Rieznicek, S. A., and J. Svoboda, Tundra communities along a microenvironmental gradient at Coral Harbour, Southampton Island, N.W.T., Naturaliste Can. (Rev. Ecol. Syst.), 109, 583-595, 1982. 
Schaefer, J. A., and F. Messier, Composition and spatial structure of plant communities on southeastern Victoria Island, arctic Canada, Can. J. Bot., $72,1264-1272,1994$.

Shaver, F. R., A. E. Giblin, K. J. Nadelhoffer, and E. B. Rastetter, Plant functional types and ecosystem change in arctic tundras, in Plant Functional Types, edited by T. M. Smith, I. A. Woodward, and H. H. Shugart, pp. 153-173, Cambridge Univ. Press, New York, 1997.

Sheard, J. W., and D. D. Geale, Vegetation studies at Polar Bear Pass, Bathurst Island, N.W.T. I. Classification of plant communities, Can. J. Bot., 61, 1618-1636, 1983.

Shippert, M. M., D. A. Walker, N. A. Auerbach, and B. E. Lewis, Biomass and leaf-area index maps derived from SPOT images for Toolik Lake and Imnavait Creek areas, Alaska, Polar Rec., 31(177), 147-154, 1995.

Stow, D., B. Burns, and A. Hope, Mapping Arctic tundra vegetation types using digital SPOT/HRV-XS data, Int. J. Remote Sens., 10, 1451-1457, 1989.

Sturm, M., J. P. McFadden, G. E. Liston, F. S. Chapin III, C. H. Racine, and J. H. Holmgren, Snow-shrub interactions in Arctic tundra: A hypothesis with climatic implications, J. Clim., 14(3), 336-344, 2001.

Svoboda, J., Ecology and primary production of raised beach communities, Truelove Lowland, in Truelove Lowland, Devon Island, Canada: A High Arctic Ecosystem, edited by L. C. Bliss, pp. 185-216, Univ. of Alberta Press, Edmonton, 1977.

Svoboda, J., and B. Freedman, Ecology of a High Arctic lowland oasis, Alexandra Fiord $\left(7853^{\prime} \mathrm{N}, 7555^{\prime} \mathrm{W}\right)$, Ellesmere Island, N.W.T., Canada, Univ. of Toronto Press, Toronto, Ont., 1988.

Thannheiser, D., Die vegetationszonen in der weslichen kanadischen Arktis, Hamb. Geogr. Stud., 43, 159-177, 1987.

Thannheiser, D., Eine landschaftsokologische studie bei Cambridge Bay, Victoria Island, N.W.T., Canada, in Beitrage zur landschaftsokolgie und zur vegetationsgeographie, pp. 1-51, Geogr. Ges., Hamburg, Germany, 1988.

Thompson, D., A classification of the vegetation of Boothia Peninsula and the Northern District of Keewatin, N.W.T., Arctic, 33(1), 73-99, 1980.

Walker, D. A., An integrated vegetation mapping approach for northern Alaska (1:4 M scale), Int. J. Remote Sens., 20, 2895-2920, 1999.

Walker, D. A., Hierarchical subdivision of arctic tundra based on vegetation response to climate, parent material, and topography, Global Change Biol., 6(Suppl. 1), 9-34, 2000.
Walker, D. A., and A. C. Lillie, Proceedings of the Second Circumpolar Arctic Vegetation Mapping Workshop, Arendal, Norway, 19-24 May 1996 and the CAVM-North America Workshop, Anchorage, Alaska, USA, 14-16 January 1997, edited by D. A. Walker and A. C. Lillie, p. 61, Inst. of Arct. and Alp. Res. Occas., Boulder, Colo., 1997.

Walker, D. A., et al., Energy and trace-gas fluxes across a soil $\mathrm{pH}$ boundary in the Arctic, Nature, 394(6692), 469-472, 1998.

Walker, M. D., Patterns and causes of arctic plant community diversity, in Arctic and Alpine Biodiversity, edited by F. S. I. Chapin and C. Körner, pp. 3-20, Springer-Verlag, New York, 1995.

Walker, M. D., D. A. Walker, and N. A. Auerbach, Plant communities of a tussock tundra landscape in the Brooks Range Foothills, Alaska, J. Veg. Sci., 5, 843-866, 1994.

Walker, M. D., W. A. Gould, and F. S. Chapin III, Scenarios of biodiversity changes in arctic and alpine tundra, in Scenarios of Future Biodiversity, edited by F. S. Chapin III, O. Sala, and E. Huber-Sannwald, pp. 83-100, Springer-Verlag, New York, 2001.

Walker, D. A., et al., Phytomass, LAI, and NDVI in northern Alaska: Relationships to summer warmth, soil $\mathrm{pH}$, plant functional types, and extrapolation to the circumpolar Arctic, J. Geophys. Res., doi:10.1029/ 2001JD000986, in press, 2002.

Webber, P. J., Spatial and temporal variation of the vegetation and its productivity, Barrow, Alaska, in Vegetation and Production Ecology of an Alaskan Arctic Tundra, edited by L. L. Tieszen, pp. 37-112, SpringerVerlag, New York, 1978.

Yurtsev, B. A., Floristic division of the Arctic, J. Veg. Sci., 5, 765-776, 1994.

Zoltai, S. C., and J. D. Johnson, Vegetation-Soil Relationships in the Keewatin District, Can. For. Serv., Fish. and Environ. Can., Ottawa, 1979.

Zoltai, S. C., D. J. Karasuik, and G. C. Scotter, A Natural Resource Survey of the Bathurst Inlet Area, Northwest Territories, Parks Canada, Ottawa, 1980 .

W. A. Gould, International Institute for Tropical Forestry, USDA Forest Service, P.O. Box 25000, Rio Piedras 00928-5000, Puerto Rico. (wgould@) fs.fed.us)

M. Raynolds and D. A. Walker, IAB, University of Alaska, 311 Irving I, P.O. Box 757000, Fairbanks, AK 99775-7000, USA. 